\title{
Community engagement and professionalisation: Emerging tensions
}

An increase in community engagement by governments across Australia's three-tiered federal polity conforms to international trends. It represents a multi-dimensional institutionalisation of participatory democracy designed to involve the public in decisionmaking. Increasingly, it is a practice which displays the markers of professionalisation, including (self-described) professionals, professional associations and a code of ethics. The individuals who design, communicate and facilitate community engagement are placed in a unique position. Whereas most professions claim to serve both their client or employer and a greater public good, community engagement practitioners play these roles while also claiming to serve as 'guardians' of democratic processes. Yet the claimed professionalisation of community engagement is raising some questions: Is community engagement really a profession - and by what criteria ought this be assessed? What tensions do community engagement practitioners face by 'serving multiple masters', and how do they manage these? More pointedly, how can ethics inform our understanding of community engagement and its professionalisation? This paper examines the case for the practice of community engagement as a profession using Noordegraaf's (2007) pillars of pure professionalism as a guide. It then explores some practical examples of the tensions practitioners may experience. The paper concludes by reflecting on the future direction of community engagement given its positioning.

\section{Introduction}

In the past half-century, public participation, also labelled community engagement in Australasia (see Bell and Hindmoor 2009), has emerged as a near-ubiquitous feature of public-state relations globally (Dean 2016, p. 213) and as a social, economic and political force, both inside and outside of governments (see, for example, Head 2011). Activities range from salient, legally-mandated processes, such as public hearings and submissions (Innes and Booher 2004; Fung 2015) through to participatory innovations such as collaborative governance (Aulich 2009; Bingham et al. 2005) and participatory budgeting (Fung 2006; Pateman 2012; Christensen and Grant 2016). Although the spectrum of activities that can be considered community engagement is broad, the binding attribute is that they involve communities and stakeholders in decision-making, or at least in making contributions to decision-making processes, around policies, plans or programs (Quick and Bryson 2016, p. 158).

As community engagement has become established, so too have those who practise it. The roles of public participation practitioners have recently gained scholarly attention 
(Hendriks and Carson 2008; Cooper and Smith 2012; Bherer 2017a; 2017b; Lee 2014; Lee 2015; Lee et al. 2015; Grant and Drew 2017) as observers have begun to recognise that these practitioners, who often deploy the label of 'professional' in their self-descriptions (see, for example, Bherer et al. 2017a; Lee 2015; Cooper and Smith 2012) are not merely one variable, or input, in a democratic process, but that potentially they are the people who conceive, legitimise, facilitate and profit from the process (Mazeaud and Nonjon 2013,p.2).

The claim of being 'professional' by practitioners might be considered as a step towards establishing the practice as a 'profession'; bringing with it status and recognition. However, the concept of a 'profession' is one which is much contested (Evetts 2013; Tapper and Millett 2015; Sciulli 2005) and has important ethical dimensions (see Tapper and Millett 2015 for a detailed analysis). Throughout this paper, the term 'profession' is used in the broad sense, articulated by Evetts (2013, p. 781) as 'essentially the knowledge-based category of service occupations which usually follows a period of tertiary education and vocational training and experience'. Consequently, 'professionalisation' is understood as the process designed to achieve the status of profession, and 'professional' is understood as denoting a member of a profession. The concept of professionalism is critically explored as it pertains to the practices of community engagement and the claims to professionalisation associated with these.

It is, however, worth noting that there are more nuanced conceptualisations of the term 'profession', such as Tapper and Millett's (2015) exploration of the concept. They highlight the 'formal' element of the concept as 'employing dangerous (or potent) knowledge in pursuit of a public good by people of good character who behave ethically in the use of that knowledge' (Tapper and Millett 2015, p. 16). The 'formal' sits opposed to the 'material' element which varies without changing the nature of the concept (Tapper and Millett 2015, p. 
12). These concepts will also be deployed in my critical discussion of community engagement as a profession.

Arguably, the putative professionalisation of community engagement practitioners is itself relatively mundane, given that 'the labor force as a whole is in one way or another becoming professionalised' through increasing specialisation, standardisation and regulation, monitoring and certification (Wilensky 1964:137). However, what is significant is the unique placement of community engagement practitioners, whether they be private sector providers - paid consultants - or public sector employees, as intermediaries between communities and public institutions as facilitators of democracy. In other traditions, 'professionals serve clients and employers and, ostensibly, society as a whole through [their] service' (Kultgen 1988, p. 4). Community engagement practitioners serve clients and employers; yet they are also required to directly and overtly serve society so that the claim of directly enhancing democracy can be substantiated (Hendriks and Carson 2008; Lee 2015). Arguably, the work of community engagement can comprise the very nexus between the community on the one hand and the polity (particularly the local polity) on the other. Crucially, those who practise community engagement for financial remuneration are also seeking either remuneration for their services (in the case of public sector employees) or to establish a credible 'fee for service' relationship (in the case of private consultants), accompanied by the range of issues that characterise principal-agent relationships (see Lane 2005). Thus, community engagement practitioners are often simultaneously the service provider, the financial beneficiary, the designers of democratic process and principles and, the guardian to these processes.

These multiple roles and the tensions they create have been acknowledged, in part, by recent research. In their chapter 'Who's the client? The sponsor, citizens, or the participation process' Bherer et al. (2017a) discuss how practitioners seek to reconcile tensions between commercial interest and the need to remain impartial. In their discussion of the 
commercialisation of deliberative democracy, Hendriks and Carson (2008, p. 309) conclude that commercialisation has not yet had a negative effect upon processes or outcomes.

However, Lee (2014, p. 495) argues that practitioners 'seem to be actively struggling with tensions and glossing over them at different moments in their work'. This line of enquiry has been developed in later work (Lee 2015; Lee et al. 2015) where it is emphasised that democratic participation is no longer a 'do-it-yourself' proposition for the citizenry such as the grassroots activism from the late 1960s was; rather it is facilitated by bureaucratic systems and community engagement practitioners (see also Grant and Drew 2017, pp. 254257).

The roles of designer and of guardian of democratic process and democratic principles (see, for example, Buhlmann et al 2008; Held 2006; Hyden 1997) places the community engagement practitioner in a precarious, yet ultimately privileged position and it is one that has democracy and its normative principle of participation as a cornerstone. At the level of normative theory, participation is frequently praised as an element of democracy, with some observers arguing that it brings significant benefits and that more is needed (see, for example, Norris 2002; Hindess 2002). Proponents for the affirmative often commence their case with an account of classical Athenian democracy (see Held 2006, p. 11-28) then trace through theories such as Rousseau's (2002) rejection of representative democracy and his aspiration for a volonte general, or 'general will' of the people, and de Tocqueville's (2009) advocacy of the democratic skills, political efficacy and collective problem-solving solutions that result from participation.

Yet doubts continue to haunt the principle of participation as evidenced by a number of trends: the ideological appeal of minimal or no participation to some individuals and political parties; technocratic public administration trends such as New Public Management (NPM) which provide limited budgets for public participation (Mulgan 2001; Martin 1998); and, a 
lack of clarity about where public participation fits within regulatory and statutory contexts that are primarily geared towards representative practices (Christensen and Grant 2016). Moreover, there is an ongoing debate about whether community engagement practices are responding to a perceived 'democratic deficit', or if they themselves are creating the demand for their services (see Mazeaud and Nonjon 2017). For instance, in their empirical research of Italian practitioners, Lewanski and Ravazzi (2017) suggest that most practitioners are seeking to address the democratic deficit by rebuilding trust; regaining legitimacy and providing transparency rather than shifting political power away from representatives. Alternatively, for their part, Grant and Drew (2017, pp. 254-257) question the normative ascendance of participation over representative arrangements and the roles of private providers in this, suggesting that the de-politicisation provided by community engagement practices serves the interest of both the providers and politicians. Moreover, Aulich's (2009, p. 44) comment that citizen participation has 'almost universal acceptance' is telling, for it is the 'almost' that indicates a lack of certainty concerning the place of participation in democracy. Because community engagement is an, as yet, underscrutinised practice, an exploration of its putative professionalisation is opportune.

There are four main parts to the paper. First, a concise account of how professionalisation has been understood is provided, focusing principally on work by sociologists. This incudes a framework of professionalism by Noordegraaf (2007) which serves as a foundation for the second part of the paper, discussing whether the practice of community engagement is a profession. Third, a series of short vignettes is presented which serve as practical examples to illustrate the tensions community engagement practitioners may experience. The concluding discussion focuses on the three questions raised in the abstract: Is community engagement really a profession? What tensions do community engagement practitioners face by 'serving multiple masters'? And, how can ethics inform our understanding of community engagement 
and its professionalisation? While these questions are not addressed definitively, reflections are made with the intention of beginning a larger conversation.

\section{Professionalism}

Writings on and conceptualisations of professionalism have been dominated by sociologists since the 1920s. Contributions have included those that can be broadly cast as adopting a functionalist perspective, wherein the professions are viewed as a positive and stabilising force for society (Tawney 1921; Carr-Saunders and Wilson 1933). In the 1950s and 1960s the 'checklist' or 'trait' approach became common (Greenwood 1957; Millerson 1964; Wilensky 1964). While this approach has been subject to numerous criticisms, such as its inability to consider the causal relationship between traits (Martimianakis et al 2009, p. 831) or an inability to explain the appeal of professionalism and why some occupations have more power than others (Evetts 2006, p.519), it remains popular in practice, with evidence of it found in most professional associations (Martimainakis et al 2009, p.831). These criticisms were responded to in a third approach, a major shift, grounded in social constructionism and neo-Weberian theories, which sought to examine how professions 'carve[d] out their privileged location in the division of labour', thus introducing a political economics to the study of professionalism (Martimianakis et al. 2009, p.832). Research began to explore critically the political and economic goals of professional organisations and institutes seeking professional jurisdiction and legitimacy and examined how they sought and affected market closure (Abbott 1988; Larson 1977; Freidson 1986). This work was followed by a focus on social and cultural inequalities (see for example Witz 1992; Beagan 2001). Recent research in professionalism has seen an emphasis placed on the role of organisations in professions and their interactions with changing management approaches (Muzio and Kirkpatrick 2011; 
Noordegraaf 2015; Evetts 2011). For instance, Muzio et al. (2011) argue that traditional 'collegial' professionalisation is making way for a new 'corporate' professionalism.

One of Noordegraaf's (2007) conceptualisations of professionalism, which serves as a useful framework for this discussion, is 'pure' professionalism. 'Purified professionalism', argues Nordegraaf (2007, p.771) is one which adopts the traditional understanding of professionalism and uses a clear definition. The framework outlines two 'pillars': First, what professionals know and do (i.e., 'content'); second, the associations that give them privileges (i.e., 'control').

FIGURE 1: Noordegraaf's (2007) Pillars of Pure Professionalism

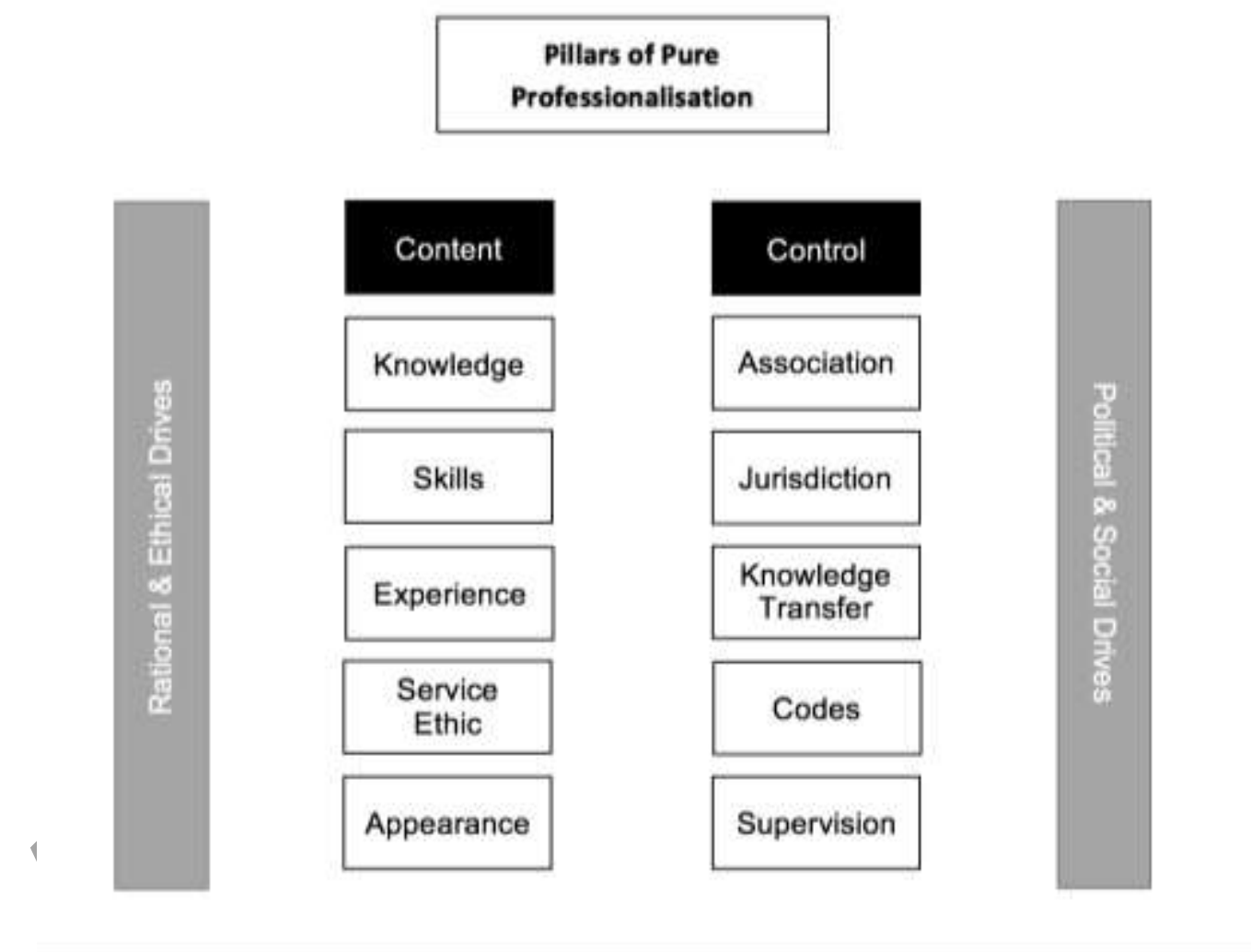

Source: Adapted from Noordegraaf (2007).

Examining Figure 1, the 'content' pillar is supported by the knowledge and skills individuals have acquired, many of which are codified to ensure exclusivity (Wilensky 1964). Knowledge and skills are portrayed as traditionally being sourced from intense tertiary 
learning, where inductees (my phrase) learn the approach of their profession. The knowledge can be abstract, general or esoteric and the professionals make inferences and use standardised skills to treat cases (Noordegraaf 2007, p. 766). The knowledge is codified to assist the professional; also to create a barrier to market entry to practice, hence creating occupational, as well as social closure (Weber 1946) or exclusivity. Through practice, individuals gain experience and learn how to behave and demonstrate the appropriate service ethic so they know how to react and respond in their role. Alternatively, the 'control' pillar refers to institutional control exercised by professionals (Freidson 2001; Abbott 1988). Thus, one form of control is professional associations, which exercise regulatory and institutionalizing functions over the profession, such as selecting and rejecting members, introducing standards and codes and establishing mechanisms for communication. Jurisdiction is then created using laws and licensing which all act to standardise knowledge and skills as well as the training and selecting of members and enforcement of codes of conduct (Abbott 1988). Knowledge is transferred through training as well as other professionalisation activities, including conferences, journals and magazines and codes which allow professions to set rules and deal with those who transgress. The professions are supervised with reward and punishment practices, such as: complaint policies for poor practice, and advanced membership standings such as "fellows" and "ambassadors". These codes also act as guards of a normative value systems (Evetts 2003). Noordegraaf (2007, p. 767-768) argues that these pillars and their features are underpinned by a series of 'drives': a rational drive for professionals to be better at their work; an ethical drive to guard values within the professional industry; a political drive to strengthen ideologies and gain power, privilege and status; and, a social drive to create a community and social closure amongst professionals. 


\section{Is community engagement a profession?}

A thorough survey of all community engagement practices to reach a definitive answer as to whether or not it does indeed constitute a profession is a task well outside the scope of any one paper. Nevertheless, in this context we can critically consider the field of community engagement against the theory of professionalism using Noordegraaf's (2007) pillars of pure professionalism as a framework. A useful entry point to so-doing is provided by the June 2014 'Special Issue' of the Journal of Public Deliberation, where writers were asked to assess the state of the field of public deliberation, with their responses including reflection upon the more profound question of 'is there a field?' (Black et al. 2015, p.1). While Black et al.'s (2015) avoidance of the term 'profession' here is perhaps indicative of an implicit wish to not engage with both the issue of professionalism and, as such, to place explicitly normative considerations to one side, they nevertheless deduce three main points. First, while there are shared beliefs and purposes amongst practitioners (Black et al. 2015, p.1), there is no consensus about the purpose of public deliberation. Second, community engagement work is often 'dismissed' by those with power and authority - or as Black et al. (2015, p.2) state: 'perhaps the stickiest challenge is that people with positional authority (e.g., policy-makers) and structural advantages (e.g., the wealthy) can easily disregard our work'. Third, that there is lot of potential for the work of community engagement to address large and complex societal issues utilising public deliberation, but that it has not yet lived up to this promise, with 'larger implication[s] ...not well understood or articulated outside of our sphere' (Black et al. 2015, p. 5). These reflections are relatively recent and can (arguably) reasonably be shared beyond public deliberation and into public participation, dialogue, or community engagement. While this example suggests that the field, or profession, does not yet appear 'fully formed' (my phrase) in the entrenched senses explored by the professionalism literature discussed above, it does suggest that that there is what I will describe as some 
semblance of a profession. This in turn suggests that there is also some semblance of a professional.

Noordegraaf's (2007) pillars, illustrated in Figure 1, provide a robust framework to reflect on this emerging field of community engagement and reveal the multidimensional, if ambiguous, nature of its professionalism. Examining Figure 1, the content pillar identifies what professionals know and do: namely, the features of knowledge, skills, experience, service ethic and appearance. Specialist knowledge provides the basis upon which professionals exercise their ability to decide, analyse and advise, or, the ability to apply theory. Professionals undertake the tasks of deduction, analysis and advising, and evidence, reasoning and skills are used to do this. In the field of community engagement, however, there is a distinct lack of a cohesive body of knowledge, including substantial empirical evidence, with common terminology only being used from the 1970s and relevant research scattered through the journals of a number of disciplines, including political science, public administration, social work, community development, and planning and environment (see, for example, Bingham et al. 2005; Innes and Booher 2004; Eversole 2010). In their study of professionalism in public relations Breit and Demetrious (2010, p.24) came to a similar conclusion, arguing that public relations knowledge is both general, rather than specialised, and 'thin' or experiential, Breit and Demetrious (2010, p.24) concluded that this makes the public relations profession vulnerable to other professional groups wanting to acquire access and influence. Arguably, similarities can be drawn with community engagement and other associated disciplines, such as communications and community development. It is this lack of a cohesive body work that is the most significant barrier to the field being deemed a profession, at least using Noordegraaf's (2007) pillars.

While the body of knowledge used by community engagement practitioners is elusive, there is stronger evidence to suggest that there is a common set of skills and experience, the 
subsequent elements in Noordegraaf's (2007) pillars. Those most often referred to include: process design skills; communication skills; and most significantly, facilitation skills (Lee et al. 2015; Quick and Sandfort 2017; Mazeaud and Nonjon 2017; Cooper and Smith 2012; Mansbridge et al. 2006; Chilvers 2017). In a study of UK practitioners, Chilvers (2017, p.122) argued that expertise, while informed by theories, 'is fundamentally grounded in personal experience, learning by doing, and an ethical commitment to empowerment' and that facilitation is perceived as a 'learned art, craft, or skill'. The feature of a 'service ethic' refers to a shared motivation to provide a public good, a feature which, although poorly documented, is likely present in community engagement professionals, given its activist roots (Floridia 2017). In these practices of skills, experience and service ethics, community engagement appears to have stronger claim to be considered a profession.

The final content feature of 'appearance' refers primarily to behaviours, speech and dress, a feature that has not been commented on in research specific to community engagement practitioners. According to Noordegaaf's (2007, pp. 776-7) framework, this pillar is underpinned by the rational and ethical motivations of professionals themselves, the rational being the desire to problem-solve, provide better service and better outcomes, while the ethical component is exemplified in the drive to guard the service ethic and certain values. This aspect is discussed in more detail below.

Again examining Figure 1, the second pillar - 'control' - consists of association, jurisdiction, knowledge transfer, codes and supervision. Noordegraaf (2007, p.767) defines associations as those that control and regulate practice either formally or informally. Professions typically do this by establishing professional associations which set codes of ethics and competencies. They then determine how these codes and standards will be achieved and maintained; admitting and denying entrance based upon licensing and admission procedures and investigating complaints and issues of incompetence (Evetts 2014, 
p.43). The largest association for community engagement practitioners in Australasia is the regional affiliate of the International Association of Public Participation (IAP2) which comprises 2,795 members (IAP2 Australasian staff member 2016, per comm 25 February). There are other related organisations, such as those for facilitators, as well as 'Engage 2 Act', a newly-formed community engagement 'collective of individuals committed to progressing high quality community engagement practice' (E2A 2017). However, IAP2 is arguably the most well-established professional association for community engagement practitioners in Australia and New Zealand. IAP2 has established a popular training program; it has partnered with the US-based Deliberative Democracy Consortium (DDC) to produce the Journal of Public Deliberation; it has produced a list of 'Core Values' which are used to judge best practice process awards in affiliate regions and globally; and promoted a Code of Ethics for practitioners (IAP2, n.d.). However, while there is evidence of quality assurance standards from the Australasian affiliate (IAP2A 2015) of the Association, there is no evidence that there are features in place that would ensure its control and regulation of the sector. This suggests that when assessed against this element of Noordegaaf's (2007) framework, the practice of public participation is not a profession.

There is also little evidence that the field has established a discrete jurisdiction and has established restrictions concerning the transfer of knowledge. Knowledge transfer has been regarded as tantamount to professional control (Abbott 1988) and includes the ability to legally, and socially, restrict those who practise a profession, thus exercising social closure as described by Weber (1946). When discussing his professional systems model, Abbott (1988) explains that traditional professions gained jurisdiction by specialising in abstract and esoteric knowledge and have constantly refined the boundaries of this knowledge to ensure survival. Yet beyond the creation of a certified professional program recently established by the United States IAP2 affiliate (IAP2USA 2017), which could be considered a first step to 
exercising Weberian closure, there is little evidence that the community engagement field has engaged in acts of jurisdiction-making and closure. For instance, in a recent exploration of the participatory democracy market in France, Mazeaud and Nonjon (2017, p.47) argue that the market is 'fragmented and competitive' and made up primarily of consultancies who offer public participation services as an additional 'a la carte' offering to their primary consulting services. Without detailed empirical data it is difficult to assess whether or not the situation is the same in Australia, although it has been alluded to in some research (see, for example, Hendriks and Carson 2008).

On the contrary, the idea that community engagement services are being provided as a 'secondary service set' to other disciplines, such as planning, engineering and public relations, would suggest that there is not a professional jurisdiction for community engagement. While there are training programs, there are not the extensive educational programs that exist in other professions that are required for admission into a professional association. For instance, in their 2009 purposive survey of 345 predominantly North American-based public deliberation practitioners, Lee and Polletta (2009) found that practitioners hold advanced degrees and certificates in a variety of disciples, including education; conflict resolution, public administration, communications, business and law. Following on from this, Lee $(2015, \mathrm{p} .44)$ reports that many practitioners 'maintain footholds in other types of consulting' (see also Bherer et al. 2017b), thus supporting the point of Breit and Demetrious (2010). Training programs include those provided by IAP2. In 2015/2016, 155 courses were conducted for 2,479 participants in Australian and New Zealand (IAP2A 2016). Lee and Polletta (2009) identify a number of other training programs in the field, of which most are skill or technique-specific. Again, this evidence suggests that the practice of community engagement is not a profession when assessed against this criterion. 
Also listed in Noordegaaf's (2007) 'control' pillar is the feature of 'codes' which refer to informal and formal codes such as codes of ethics. As with many professions and communities of practice, a code of ethics exists for community engagement practitioners, although its use and prevalence is unknown. The 'IAP2 Code of Ethics' (IAP2, n.d.) provides members with principles to guide how individuals should practise community engagement. It also provides members with a list of 'Core Values' (IAP2, n.d.), a set of principles which set out what a good community engagement process is.

The final feature of Noordegaaf's $(2007$, p. 76$)$ 'control' pillar in Figure 1 is that of supervision, which speaks to procedures for 'dealing with complaints and punishing members' and supporting members to negotiate their practice and their ethics. In many professions, codes of ethics serve as the rulebook which, when applied, highlight shortfalls in practice (for a discussion, see Breit and Demetrious 2010, p.23). For community engagement practitioners, there is no supervision or repercussion for not adhering to a code of ethics, beyond market repercussions. Given that community engagement practitioners are not compulsorily accredited in any way and membership appears open to all, this feature is noticeably absent. This pillar is underpinned by the political drive of practitioners to gain power and status as well as social drives to form communities and create social closure, as shown in Figure 1. Noordegraaf (2007, p.768) states that these drives, along with the rational and ethical drives, 'balance each other', although this is not always the case, with imbalances resulting in unprofessionalism - however ambiguously defined this is.

It is worth underscoring the limitations of Noordegraaf's (2007) framework, something he does himself. Frameworks such as the 'pillars of pure professionalism' fail to answer a number of conceptual questions in the context of knowledge societies with flexible specialisations. Questions such as: Where does professionalism in the public sector fit? How does it work with bureaucracies? What about the increasing importance of the organisations? 
What about the priority of efficiency and austerity? (Noordegraaf 2007, p. 769). In seeking to address these questions, Noordegraaf argues that three types of professions can be identified: 'pure' (as outlined), 'situated' and 'hybridized'. Situated professionalism is defined by broadening professionalism from traditional professionals to include experts, while hybridized professionalism is a reinterpretation where reflective practitioners require links to the outside world (Noordegraaf 2007; Noordegraaf 2015). While the field of community engagement does not align with the 'pure' type of professionalism, it may align with the 'situated' or 'hybridized' approaches. Even so, we ought to be aware that this broadening of the criteria for what constitutes a profession serves the interests of those fields of practice that do not fit the 'pure' type, in that the claim to the label allows them to exercise forms of Weberian closure discussed above.

\section{Tensions}

While the discussion of professional status is likely to persist for the years to come, practitioners have a more pressing concern: how to manage the emerging tensions that professionalisation is bringing. To illustrate this point, three vignettes are presented. I then explore how professional ethics might assist in broadening understanding.

1. A consultancy is appointed to design and deliver a potentially contentious project for a government client. The job is assigned to the principal and a junior consultant. At the same time as winning this job the consultancy wins a number of other jobs, limiting the time the principal can spend on the project and the bulk of the work falls to the junior consultant. Toward the end of the delivery of the project, the junior consultant realises they have forgotten to identify and engage with a major stakeholder group. It is likely the input from this group would significantly alter the project outcome and it would also make a large amount of the costly technical work done to date void. The contract is due to end in two weeks. The junior consultant is unsure if they should attempt to include this stakeholder group at this late stage as there would be a cost to both their consultancy and the government organisation as well the risk that the other stakeholders would become disgruntled at having spent a great deal of time working towards an outcome only to have it change.

2. A practitioner based inside a government organisation is in the final weeks of a large deliberative process which has spanned several months. Participants constitute a 'minipublic' and together they have developed three options and are now also been tasked with 
selecting the final outcome. The elected representatives have seen these options and have a strong preference for one. The elected representatives know they have declared they will support the option the group chooses, but they are keen to see if there is some way that their favoured option could be chosen. The practitioner values the relationship with the elected representatives and is wanting to build the profile and budget allocation of engagement within the organisation.

3. A consultant is appointed to design and deliver a process for a large public service organisation. The contract is for a significant sum of money. In the early weeks of designing the engagement process, there are some changes to the project and the consultant realises that there is no influence available for the community about to be consulted. They could suggest re-scoping the process to a smaller and less-costly communications exercise or say nothing and receive the larger, and anticipated, financial remuneration.

These vignettes illustrate the tensions community engagement practitioners, both internal and external to organisations, may experience in their roles. They touch on issues of neutrality, transparency, commercial interests, personal interest, supervision, independence and inclusivity inter alia. This paper has thus far hinted at how professional ethics may bring some understanding and clarity to these tensions. The themes of public good, good practitioners and good actions by practitioners are all relevant.

Working with the public to determine what the public good is, is what most community engagement practitioners would espouse as the very essence of their work.

Professionals seek to determine who is affected and will then work with those people to assist them in determining what they perceive is their greatest good. Examining the first vignette, to decide about the greatest good for the majority affected without engaging them would not only be inherently undemocratic; it would also contradict the claims that community engagement enhances decision-making and ensures the sustainability of those decisions. The tension for practitioners, however, is: when should this outcome-focused approach to collective decision-making be prioritized over other ethical approaches to decision-making such as rights-based approaches? Should practitioners and participants work to an agreed set of moral principles across all decisions? Who decides what the public good is and how it is known? For example, is there is a moral obligation to involve the missing stakeholder group? 
The theme of the good practitioner is also pertinent in community engagement practice. What character traits and principles are required to make a good community engagement practitioner? The literature suggests (sometimes inexplicitly) that community engagement practitioners should demonstrate openness, transparency, inclusivity, and probably most significantly, neutrality (Mansbridge et al 2006; Moore 2012; Spada and Vreeland 2013). There is, however, no widely-accepted consensus on which virtues should be included and prioritized over others. For example, in the second vignette, should the practitioner prioritise their neutrality above all else - including their strategic (and potentially financially rewarding) relationship with the particular set of elected representatives - and the potential for more work on the basis of being recommended to other elected groups by this particular cohort? For community engagement practitioners, is neutrality a form of selfinterest, and if it matches with participants, is it of concern? Do delineations of who commissions and pays for the work change perceptions or is it likely that the work is still associated with the organisation responsible for the engagement?

Finally, there is the issue of how to understand good actions by practitioners. Is it unreasonable, or unethical, for practitioners to put their needs above those of the client or the democratic process? Should practitioners be wholly self-interested, wholly altruistic or neither? For example, in the third vignette, should the practitioners act in their own interest or that of the client and community?

As a relatively new and underscrutinized practice, there is little to no guidance for practitioners as they face these dilemmas. As previously mentioned, IAP2 provides members with a Code of Ethics for practitioners and Core Values to guide practice but there is no evidence that they are widely used, especially given the disparity and fragmentation of practitioners. 


\section{Broader Observations}

The abstract for this paper posed a series of questions: Is the practice of community engagement really a profession - and by what criteria is it assessed as such? What tensions do community engagement practitioners face by 'serving two masters', and how do they manage these? How can ethics inform our understanding of community engagement and its professionalisation? Such large questions would require more time to answer; although this paper is an attempt to critically think through these issues.

To the question of whether community engagement is a really a profession Noordegraaf's (2007) pillars of pure professionalism provide a useful framework to assess the current state of the practice of community engagement. As outlined at the beginning of this section, it is not the intention of this paper to provide a definitive ruling on whether or not the community engagement field has reached professional status. By discussing elements of professionalism, as outlined by Noordegraaf (2007), a profile of the field can begin to be understood. The discussion has shown that the field has developed in the elements of skills, experience and service ethics - all 'content' features. It is however under-developed or only partially-developed in the elements of knowledge, appearance, association, jurisdiction, knowledge transfer, codes and supervision. It is the absence of a cohesive body of knowledge, one which has its own boundaries rather than drawing parts from other disciplines as well as a clearly defined jurisdiction within which to operate, which is the most significant gap using this framework. However, given the presence of the other elements, it can be determined that there is some semblance of a profession in community engagement practice. Understood as such, community engagement could be comparable with teaching, where the body of knowledge draws from others yet a strong skill base is required to be effective and a strong service ethic is evident. It is more developed than hairdressing, which also requires skills but does not require a service ethic and commitment to the public good - 
teaching and hairdressing are the two examples of practices used by Tapper and Millett (2015) in their discussion.

To the question of what tensions community engagement practitioners face: as it is currently undertaken, community engagement practitioners act as intermediaries between communities and public institutions as facilitators of democratic processes. On the one hand they are required to balance a principal-agent relationship between themselves as service providers and their clients; on the other hand they are also assumed to be guardians of democratic processes and to advocate for the role of participants and the wider community. The vignettes presented in section four are an attempt to highlight how these tensions manifest, and how they call to question issues around neutrality, transparency and commercial demands.

Finally, to the question of how ethics can inform our understanding of professionalisation and community engagement. By examining collective decision-making models for determining public good, practitioners can consider what ethical approach is the most suitable in any given situation. By examining the character traits and virtues that make a good practitioner, individuals can identify which virtues should take priority in differing situations. And by examining how to ensure their actions are good, practitioners can consider their motivations and the impacts these may have. Of course, these examinations will not guarantee an ethical practice, but the examinations, and ensuing discussions, will oblige the practice and the practitioners to develop ethical ways to negotiate complexities and conflicts that will inevitably arise in their practice.

To conclude, community engagement practitioners are uniquely placed at a nexus between communities and institutions, with loyalties balanced between their clients (or employer) and democratic principles. There is an opportunity for the field to support practitioners in making good and ethical decisions in the face of the inevitable dilemmas that 
arise from their position. How to do this is a valuable conversation in itself for practitioners.

For instance, they may wish to consider how to build a more reflective practice; what knowledge and skills practitioners need to make ethical decisions; and how these could be provided and integrated. Missing this opportunity is likely to have adverse effects on practitioners, the institutions they serve and democracy.

\section{Acknowledgements}

I would like to thank both reviewers for their considered comments and suggestions which have vastly improved the paper from its original iteration. Specifically, thanks to Reviewer 1 for their suggestion of including examples that demonstrate the practical issues. Considerable thanks must to go to Reviewer 2 for their substantial comments and suggestions which also included the suggestion of real scenarios as well as others relating to the ethical analysis and the nomenclature of key concepts. Thanks also to the editor for their suggestions and swift guidance of the paper through the numerous phases. 


\section{References}

Abbott, A. (1988). The Systems of Professions: An Essay on the Division of Expert Labor. Chicago: University of Chicago Press.

Aulich, C. (2009). From Citizen Participation to Participatory Governance in Australian Local Government. Commonwealth Journal of Local Governance, 2, 44-60.

Beagan, B. (2001). Micro inequities and everyday inequalities: "Race," gender, sexuality and class in medical school. Canadian Journal of Sociology, 26(4), 583-610.

Bell, S., \& Hindmoor, A. (2009). Rethinking governance: the centrality of the state in modern society. Cambridge, UK: Cambridge University Press.

Bherer, L., Gauthier, M., \& Simard, L. (2017a). The Professionalization of Public Participation. Routledge.

Bherer, L., Gauthier, M., \& Simard, L. (2017b). Who's the Client? The Sponsor, Citizens, or the Participatory Process?: Tensions in the Quebec (Canada) Public Participation Field. In L. Bherer, M. Gauthier, \& L. Simard (Eds.), The Professionalization of Public Participation (pp. 87-114). New York: Taylor and Francis.

Bingham, L., Nabatchi, T., \& O'Leary, R. (2005). The New Governance: Practices and Processes for Stakeholder and Citizen Participation in the Work of Government. Public Administration Review, 65(5), 547-558.

Black, L. W., Shaffer, T. J., \& Thomas, N. L. (2015). Reflecting on the State of our Field: Challenging our Purpose, Impact, and Potential. Journal of Public Deliberation, $10(1), 25$.

Breit, R., \& Demetrious, K. (2010). Professionalisation and public relations: an ethical mismatch. Ethical Space: The International Journal of Communication Ethics, 7(4), $20-29$.

Bühlmann, M., Merkel, W., \& Wessels, B. (2008). The quality of democracy: democracy barometer for established democracies. Zurich: Hertie School of Governance.

Carr-Saunders, S. A. M., \& Wilson, P. A. (1933). The Professions. London: Oxford University Press.

Chilvers, J. (2017). Expertise, Professionalization, and Reflexivity in Mediating Public Participation: Perspectives from STS and British Science and Democracy. In L. Bherer, M. Gauthier, \& L. Simard (Eds.), The Professionalization of Public Participation (pp. 115-138). New York: Taylor and Francis. 
Christensen, H. E., \& Grant, B. (2016). Participatory Budgeting in Australian Local Government: An Initial Assessment and Critical Issues. Australian Journal of Public Administration, 75(4), 457-475.

Cooper, E., \& Smith, G. (2012). Organizing Deliberation: The Perspectives of Professional Participation Practitioners in Britain and Germany. Journal of Public Deliberation, 8, $1-39$.

Crane, A., \& Matten, D. (2016). Business Ethics: Managing Corporate Citizenship and Sustainability in the Age of Globalization (Fourth edition). Oxford: Oxford University Press.

de Tocqueville, A. (2009). Democracy in America (Vol. I \& II). The Floating Press.

Dean, R. J. (2016). Beyond Radicalism and Resignation: The Competing Logics for Public Participation in Policy Decisions. Policy and Politics.

[E2A] Engage 2 Act. (2017). A Community Engagement Collective $\mid$ Engage 2 Act. Retrieved August 29, 2017, from https://www.engage2act.org/

Eversole, R. (2012). Remaking participation: challenges for community development practice. Community Development Journal, 47(1), 29-41.

Evetts, J. (2003). The Sociological Analysis of Professionalism: Occupational Change in the Modern World. International Sociology: Journal of the International Sociological Association, 18(2), 395-415.

Evetts, J. (2006). Introduction: Trust and Professionalism: Challenges and Occupational Changes. Current Sociology, 54(4), 515-531.

Evetts, J. (2011). A new professionalism? Challenges and opportunities. Current Sociology, $59(4), 406-422$.

Evetts, J. (2013). Professionalism: Value and ideology. Current Sociology. La Sociologie Contemporaine, 61(5-6), 778-796.

Evetts, J. (2014). The Concept of Professionalism: Professional Works, Professional Practice and Learning. In S. Billet, C. Harteis, \& H. Gruber (Eds.), International Handbook of Research in Professional and Practice-based Learning (pp. 29-56). Netherlands: Springer.

Floridia, A. (2017). From Participation to Deliberation. A Critical Genealogy of Deliberative Democracy. Colchester (UK): ECPR Press.

Freidson, E. (1986). Professional Power: A Study of the Institutionalization of Formal Knowledge. Chicago: The University of Chicago Press. 
Freidson, E. (2001). Professionalism, the third logic: on the practice of knowledge. University of Chicago press.

Fung, A. (2006). Varieties of Participation in Complex Governance. Public Administration Review, 66, 66-75.

Fung, A. (2015). Putting the Public Back into Governance: The Challenges of Citizen Participation and Its Future. Public Administration Review, 75(4), 513-522.

Grant, B., \& Drew, J. (2017). Community and Community Engagement in Australian Local Government. In Local Government in Australia: History, Theory and Public Policy (pp. 217-264). Springer: Singapore.

Greenwood, E. (1957). Attributes of a Profession. The Social Worker, 2(3), 45-55.

Head, B. W. (2011). Australian experience: Civic engagement as symbol and substance. Public Administration and Development, 31(2), 102-112.

Held, D. (2006). Models of Democracy. Cambridge UK: Polity.

Hendriks, C. M., \& Carson, L. (2008). Can the market help the forum? Negotiating the commercialization of deliberative democracy. Policy Sciences, 41(4), 293-313.

Hindess, B. (2002). Deficit by Design. Australian Journal of Public Administration, 61(1), $30-38$.

Hyden, G. (1997). Civil society, social capital and development: Dissection of a complex discourse. Studies in Comparative International Development, 32(1), 3-30.

Innes, J. E., \& Booher, D. E. (2004). Reframing public participation: strategies for the $21 \mathrm{st}$ century. Planning Theory \& Practice, 5(4), 419-436.

[IAP2] International Association of Public Participation. (n.d.). Core Values, Ethics, Spectrum - International Association for Public Participation. Retrieved September 8, 2017, from https://www.iap2.org/?page=pillars

[IAP2A] International Association for Public Participation Australasia. (2015). Quality Assurance Standard for Community and Stakeholder Engagement. Retrieved from https://www.iap2.org.au/documents/item/391

[IAP2A] International Association of Public Participation Australasia. (2016). Annual Report 2016.

[IAP2A] International Association for Public Participation USA. (2017). IAP2 USA Professional Certification. Retrieved from https://iap2usa.org/certification Kultgen, J. (1988). Ethics and Professionalism. Philadelphia: University of Pennsylvania Press. 
Lane, J.-E. (2005). Public Administration and Public Management: The Principal-agent Perspective. Taylor \& Francis.

Larson, M. S. (1977). The Rise of Professionalism: A Sociological Analysis. Berkeley: University of California Press.

Lee, C. W. (2014). Walking the Talk: The Performance of Authenticity in Public Engagement Work. The Sociological Quarterly, 55(3), 493-513.

Lee, C. W. (2015). Do-It-Yourself Democracy: The Rise of the Public Engagement Industry. New York: Oxford University Press.

Lee, C. W., McNulty, K., \& Shaffer, S. (2015). Civic-izing Markets: Selling Social Profits in Public Deliberation. In C. W. Lee \& E. Walker (Eds.), Democratizing Inequalities: Dilemmas of the new public participation (pp. 27-45). New York: New York University Press.

Lee, C., \& Polletta, F. (2009). The 2009 Dialogue and Deliberation Practitioners Survey: What is the State of the Field? Retrieved from http://sites.lafayette.edu/ddps/files/2010/02/Results2009.pdf

Lewanski, R., \& Ravazzi, S. (2017). Innovating Public Participation: The Role of PPPs in Institutions in Italy. In L. Bhere, M. Gauthier, \& L. Simard (Eds.), The Professionalization of Public Participation (pp. 17-39). New York: Taylor and Francis.

Mansbridge, J., Hartz-Karp, J., Amengual, M., \& Gastil, J. (2006). Norms of Deliberation: An Inductive Study. Journal of Public Deliberation, 2(1), 1-47.

Martimianakis, M., Maniate, J., \& Hodges, B. (2009). Sociological Interpretations of Professionalism. Medical Education, 43, 829-837.

Martin, J. F. (1998). Reorienting a nation: Consultants and Australian public policy. Aldershot, England: Ashgate.

Mazeaud, A., \& Nonjon, M. (2013). The contribution of the "professionals of participation" to the participatory turn. In Panel 413 : What explains the (or the absence) of participatory reforms? Bordeaux. Retrieved from https://ecpr.eu/Filestore/PaperProposal/95519b33-1c10-45da-9e44-35b1f35a18de.pdf Mazeaud, A., \& Nonjon, M. (2017). The Participatory Democracy Market in France: Between Standardization and Fragmentation. In L. Bherer, M. Gauthier, \& L. Simard (Eds.), The Professionalization of Public Participation (pp. 40-64). New York: Routledge. 
Millerson, G. (1964). The qualifying associations: a study in professionalization. London: Routledge.

Moore, A. (2012). Following from the front: theorizing deliberative facilitation. Critical Policy Studies, 6(2), 146-162.

Mulgan, R. (2006). Government Accountability For Outsourced Services. Australian Journal of Public Administration, 65(2), 48-58.

Muzio, D., Hodgson, D., Faulconbridge, J., Beaverstock, J., \& Hall, S. (2011). Towards corporate professionalization: The case of project management, management consultancy and executive search. Current Sociology, 59(4), 443-464.

Muzio, D., \& Kirkpatrick, I. (2011). Introduction: Professions and organizations - a conceptual framework. Current Sociology. La Sociologie Contemporaine, 59(4), 389405.

Noordegraaf, M. (2007). From "Pure" to "Hybrid" Professionalism. Administration \& Society, 39(6), 761-758.

Noordegraaf, M. (2015). Hybrid professionalism and beyond: (New) Forms of public professionalism in changing organizational and societal contexts. Journal of Professions and Organiszation, 2(2), 187-206.

Norris, P. (2011). Democratic deficit: Critical citizens revisted. Cambridge: Cambridge University Press.

Pateman, C. (2012). Participatory Democracy Revisited. Perspectives on Politics, 10(01), 719.

Quick, K. S., \& Bryson, J. (2016). Theories of Public Participation in Governance. In J. Torbing \& C. Ansell (Eds.), Handbook in Theories of Governance (pp. 158-169). Cheltenham, UK: Edeard Elgar.

Quick, K. S., \& Sandfort, J. R. (2017). Learning to Facilitate: Implications for Skill Development in the Public Participation Field. In L. Bherer, M. Gauthier, \& L. Simard (Eds.), The Professionalization of Public Participation (pp. 214-241). New York: Taylor and Francis.

Rousseau, J.-J., \& May, G. (2002). The Social Contract: And, The First and Second Discourses. Yale University Press.

Sciulli, D. (2005). Continental Sociology of Professions Today: Conceptual Contributions. Current Sociology, 53(6), 915-942. 
Spada, P., \& Vreeland, J. R. (2013). Who Moderates the Moderators? The Effect of Nonneutral Moderators in Deliberative Decision Making. Journal of Public Deliberation, $9(2), 1-31$.

Tapper, A., \& Millett, S. (2015). Revisiting the Concept of a Profession. Research in Ethical Issues in Organizations, 13, 1-18.

Tawney, R. H. (1920). The Acquisitive Society. New York: Harcourt Brace.

Weber, M. (1946). Class, status, party. In H. H. Gerth \& C. W. Mills (Eds.), From Max Weber: Essays in Sociology (pp. 180-195). New York: Oxford University Press.

Wilensky, H. L. (1964). The Professionalization of Everyone? The American Journal of Sociology, 70(2), 137-158.

Witz, A. (2013). Professions and Patriarchy. London: Routledge. 